Bernadetta K u c zera-Chachuls kaORCID: 0000-0002-1817-9083

„PIONOWY” WYMIAR NORWIDOLOGII

DOI: https://doi.org/10.18290/sn2139.18

W roku 2019 w wydawnictwie naukowym UAM ukazuje się książka Lidii Banowskiej pod mocnym i zalecającym się tytułem Byt $i$ światłocień. O antropologii poetyckiej Norwida. Druga część tytułu wskazuje na problem tak generalny, że tym samym czytelnik wychwytuje zapowiedź próby monografizującego ujęcia twórczości późnego romantyka.Wyjaśnienie tego frapującego tytułu, znajdujące się we wstępie, jest chyba nie do końca jasne. Tytuł wskazuje raczej na obligującą dominantę obserwacji Norwidowego człowieka (antropologii), natomiast we wstępie sprawa ironii (sygnowana zresztą pierwszym członem tytułu) zdaje się wypływać jako kwestia w pewien sposób równoważna. Autorka wyjaśnia ostatecznie: „Interesowało mnie, jak obie te sfery ze sobą interferują: przenikają się ściśle, spotykają się ściśle, spotykają w pewnym zakresie 1 u b w c a 1 e". ${ }^{1}$ (podkreśl. B.K. Ch.) Punkt wyjścia autorki w sposób nieoczywisty sugeruje jednak, że ironia Norwidowa w sposób zasadniczy decyduje o jego antropologii, a przecież tak nie jest, co stwierdzone zostaje w ostatnim zacytowaniu. Ironia jest pewną częścią tylko zachowań poetyckich tego autora, być może równorzędną z kilkoma innymi. I jeszcze jedno: czy dwupoziomowość języka Norwida wynika jedynie z ironii?

Ale można też na problem spojrzeć nieco inaczej. Mogłoby się wydawać, że ironia poety łączy się głównie z jego językiem, sposobem ekspresji, a przecież ten wymiar decyduje o tym, k i m jest mówiący, ironia w jakiś sposób rzutuje na podmiot czy też „wyłania się” z podmiotu „źródłowo” - jak u Sokratesa - ironisty. ${ }^{2}$ Wymiar ,jak"przechodzi w wymiar „kto”. Jeśli, biorąc poważnie i konsekwentnie drugą część tytułu, będziemy szukać tego przesunięcia, wówczas może okazać się, że rozprawa przeniosła myślenie o ironii Norwida na obszar nieco nowszy.

${ }^{1}$ L. Banowska, Byt i świattocień. O antropologii poetyckiej Cypriana Norwida, Poznań 2019, s. 15.

${ }^{2}$ Wydaje się jednak, że na tym obszarze panuje w książce pewien nieporządek czy brak precyzji. Zob. np. zdania: „Norwidowska synteza tradycji sokratejskiej oraz ironiczne odczytywanego przesłania Chrystusa, w świetle której poezja autora Vade-mecum ujawnia się jako kontynuowanie misji głoszenia prawdy oraz służenia słowu. W tej perspektywie ironia jako lekcja człowieczeństwa przypomina nie tylko eklektyczne demaskowanie iluzji oraz majeutyczne „rodzenie prawdy” przez nauczyciela Platona, ale okazuje się jedną z odmian naśladowania Chrystusa (imitationem Christi), tym ważniejszego, że będącego z jednym z węzłów łączących Norwidowską ironię i antropologię". 
Książka zatem podejmując dwie kwestie: ironii i antropologii Norwidowskiej, czyni z nich zakresy łącznej i warunkującej się wzajemnie problematyki; jak można sądzić z komentarzy autorki i nadrzędnej sugestii tytułu rozprawy, antropologiczny wizerunek twórczości poety jest tu najważniejszy, natomiast ironia, determinująca zarówno postępowanie Norwida poety, jak i Norwida myśliciela, jest czymś w rodzaju metanarzędzia, bez którego wydobycie obrazu człowieka z pisarstwa poety dziewiętnastowiecznego wydaje się niemożliwe

Takie postawienie problemu przez Lidię Banowską wydaje się uzasadnione, nawet w sytuacji dość opisanego już problemu ironii u Norwida (literatura przedmiotu zostaje uczciwie przywołana), natomiast tak wyraźne połączenie tej kwestii ze sprawą antropologii wyrasta z głębi problemowej zawartości pism poety i może zapowiadać oryginalną odsłonę, a także przecierać szlaki w stronę monograficznego ujęcia pism poety, które wydaje się - paradoksalnie - coraz trudniejsze.

Rozprawa łamie się na dwie części. Pierwsza, poświęcona ironii, obejmuje około osiemdziesiąt stron, druga - pozostałe z dwustu osiemdziesięciu. Zatem same objętościowe proporcje każą zobaczyć dysertację jako rzecz o antropologii Norwida.

Rozprawa ta, wykorzystując w pełni formalne „samookreślenie” poety przez wyeksponowanie miejsca ironii w jego postępowaniu - można wstępnie założyć - wypływa z głębokiego, strukturalnego uformowania całości dzieła.Chodziłoby jedynie o to, żeby te miejsca wydobyć i opisać, szczególną uwagę przywiązując do funkcjonalnej w pewien sposób obecności ironii, decydującej o nadrzędnej jej roli w kształtowaniu Norwidowskiej antropologii. Dość przypomnieć, że do chwili obecnej traktowana jako monograficzne ujęcie twórczości Norwida książka Zdzisława Łapińskiego Norwid, najobszerniejszą swoją część poświęca właśnie człowiekowi obecnemu w tej twórczości („Cóż jest człowiek?”)․ Co ciekawe, zakres źródłowy rozdziału książki Zdzisława Łapińskiego w niewielkimtylko stopniu pokrywa się z pulą komentowanych tekstów przez Lidię Banowską w drugim, antropologicznym rozdziale jej książki. Nie jest to oczywiście żaden zarzut, ileż wierszy Norwida odnosi się właśnie do człowieka? Pytanie-truizm, z którego może winnam się usprawiedliwić. Czy jest tu jakieś niedopatrzenie Lidii Banowskiej? Chyba żadną miarą. Więc może niedopatrzenie Zdzisława Łapińskiego? Niezupełnie. Natura pisarstwa artystycznego poety? Niemal każdy z wierszy Norwida wchodzi w ten problem? W dużym stopniu tak. Wydaje się, że autorka rozprawy nie do końca uwzględniła tę kwestię. Brak w książce większego odniesienia się do zagadnienia, jak właściwie można, z perspektywy badawczej, poradzić sobie z tym problemem; postawienia pytania na przykład, dlacze-

\footnotetext{
${ }^{3}$ Z. Łapiński, Norwid, Kraków 1971.
} 
go pryzmat źródłowy, przez jaki widzi się antropologię Norwida, jest tak różny u różnych badaczy? To jest ten moment, w którym mamy szanse wejść na teren specyficzności poety dziewiętnastowiecznego.

Do celów egzemplifikacyjnych wybranego zagadnienie Lidia Banowska wybiera garść liryków Norwida. Część pierwszą organizuje Ironia (rozdział „definicyjny”), część drugą Królestwo (ale także fragmentarycznie Quidam i wiersze Do Zeszłej, Pielgrzym i kilka innych) - pierwszy rozdział; drugi rozdział tej części (i zasadniczą część książki) Fatum, Śmierć i Do Zeszłej. Autorka spodziewa się zatem, że możliwie bliski ogląd pojedynczych wierszy Norwida będzie podstawową metodą rozwiązania zagadnienia postawionego we wprowadzeniu do książki.

Czy wybór wierszy do podjęcia refleksji na temat i ironii, i antropologii był odpowiedni? W jaki sposób przyczynił się do rozwiązania problemów postawionych we wstępie? Pierwszą część książki można (tymczasem) pozostawić bez komentarza (Ironia jest przecież wierszem ,definicyjnym” w rozumieniu niemal literalnym), chociaż jako dopełniający tę pulę zagadnień mógł tu również zaistnieć (hermeneutycznie niezwykle konstruktywnie) np. wiersz Ciemność; sensotwórczo bliźniaczy niemal tekst interpretowanej Ironii, uruchamiający wątek ,mechanizmu światłocienia”, podkreślający negatyw ciemności i konieczność jego zaistnienia na drodze do wydobywania prawdy.

Nieco inaczej natomiast przedstawia się sytuacja w części drugiej książki. Kompozycję rozdziału - zasadniczego rozdziału dotyczącego człowieka Norwida - wyznacza hermeneutyczny opis Fatum, Śmierci i Do Zeszłej..., jak pisze autorka - „dobranych wedle klucza sytuacji granicznych: albo dosłownie - cierpienia i śmierci, albo w sensie przenośnym - przekraczania granicy między życiem i śmiercią, a także dalszych granic, już w innym wymiarze świata" (s. 15). Tak się składa, że wiersze te należą do kilku arcydzielnych miniatur Norwidowych i kiedy widzimy je łącznie, objęte interpretacją, do której kluczem stają się ,sytuacje graniczne", cierpienie i śmierć, przekraczanie granicy, po pierwsze - narzuca się pytanie czy ich szeregowanie (tych wierszy) nie wynika jednak w dużym stopniu ze względów formalnych (Norwidowskie arcydzieła), a po drugie, czy wyczerpują one pulę utworów Norwida spełniających warunki określone przez autorkę „sytuacją graniczną"? Zwłaszcza jeśli weźmiemy pod uwagę rozpoznaną już dobrze skłonność poety do eksponowania sytuacji tragicznych, które pojawiają się w „mikroprzestrzeni” doznań człowieka (jak np. w Pierścieniu Wielkiej-Damy). Zatem już nie np. zabójstwo, spektakularna zagłada przedstawiana na scenie, ale niemal niewidoczna, upodlona godność człowieka w przestrzeni salonowych międzyludzkich relacji. Czy w tej sytuacji przywołanie Pielgrzyma (dopuszczone do 
głosu przez Lidię Banowską wiersze również zostały dotąd mocno wyeksplorowane w literaturze przedmiotu) na przykład, niemal programowej wykładni antropologii Norwida, nie byłoby konieczne? Tym bardziej, że obserwujemy w nim i ironię podporządkowaną głównemu tematowi, i subtelny sygnał cierpienia (,wy myślicie...” ) i proces ,przetwarzania” ciężarów, dotkliwości, w możliwość osiągnięcia „nieba”, chociaż o „granicach” nie mówi się wprost. Wiersz ten okazjonalnie, bez uwzględnienia niezbywalnego dla tej rozprawy całościowego potencjału sensów, wspomniany jest na s.121/122. Utworów podobnych, wpisujących się w zasadniczą dla tej książki problematykę, a także objętościowo większych, można by przywołać znacznie więcej (np. Wielkość, Litość, Larwa, Czemu). Dlaczego brak tu (tu większa forma wypowiedzi poety) np. Stygmatu, również rezonującego w przestrzeń życia i śmierci, strefę nadprzyrodzoności, chociaż ściśle, jak najczęściej u Norwida, połączonych z doczesnością? A Człowiek? A ,, A dorio ad Phrygium” na przykład? Wymienianych również przez autorkę, ale „okazjonalnie”, marginesowo...Abstrahując od artystycznego wymiaru wersów, spójrzmy na końcówkę Człowieka, wybieram dość przypadkowy fragment:

I to ja Ciebie, zrodzonego k'temu,

Mamże zawodną łudzić pomyślnością?

Byś nieświadomość swą zwał cudzą złością,

Targał się ówdzie, gdzie klaskać masz w dłonie,

A gdzie masz piorun cisnąć, skłaniał skronie? -

Nie! - ty bądź raczej nie bardzo szczęśliwy -

Pierwszym nie będziesz, ni ostatnim, przeto

Bądź niezwodzonym! - umarły czy żywy?-

Cykutą karmion czy miodem i mlekiem?-

Bądź: niemowlęciem, mężczyzną, kobietą -

Ale przed wszystkim bądź: Bożym Człowiekiem.

(PWsz II, 274)

Ileż w tym fragmencie postrzegamy rozwinięć i dopełnień Fatum, Śmierci.. Nawet specyficznie Norwidowska „graniczna” sytuacja sygnowana przez postać Sokratesa jest tu obecna („Cykutą karmion...”).

Z poematów przywołany zostaje Quidam, nieco Assunty. Czy przy tak sformułowanym temacie nie jest tych tekstów egzemplifikacyjnych trochę za mało? A przecież odnajdujemy znakomite ,,antropologicznie” fragmenty np. w Pierścieniu Wielkiej-Damy, Kleopatrze...,,napraszające się" do tworzenia myśli kontekstowych i uzupełniających. Wydaje się, że rekonstruowanie wizji człowieka (i nasyconych ironią) Norwida na podstawie kilku wierszy jest bardzo trudne, nawet jeśli 
te wiersze uzupełniane są okazjonalnie innymi tekstami poety. Obserwacje definicyjne bywają możliwe na bazie wyjętych pojedynczych utworów, natomiast całościowa rekonstrukcja ,antropologii poetyckiej” - raczej niezupełnie. Istnieje jednak możliwość obrony wyborów Lidii Banowskiej. Zakładam, że r e s p e k t u j ą c przymiotnik "poetycka” chciała autorka wybrać teksty liryczne o okréślonym zagęszczeniu treści i wyrazistej strukturalnej realizacji. Forma miniaturowa umożliwia zaostrzenie widzenia problemu, co pozostaje $\mathrm{w}$ związku $\mathrm{z}$ radykalizacją i ekspozycyjną izolacją sensów. N ow a torska, arcydzielna forma sprzyja ekspresji określonych treści, ale też kusi interpretatora. Można podejrzewać, że ten ostatni czynnik zaważył na ostatecznych decyzjach autorki co do wyboruiwykroju pola egzegezy. W takim wypadku konieczne bywa uwzględnienie (zrozumienie) niedyskursywnej, a r ty s ty c z n ej strony utworu. Spróbuję zatem przyjrzeć się niektórym fragmentom analiz i ich zwieńczeniom.

Wcześniej jednak chcę zwrócić uwagę na ważne deklaracje metodologiczne, pojawiające się we wstępie do całości (Ironia i antropologia).

[...] rys interpretacyjny książki odsłania czytanie jako podstawową perspektywę odbioru Norwidowskiego dzieła, a także przyświecający jej cel: pokazanie właściwości liryki Norwida na przykładzie centralnych dla tej twórczości zagadnień czy „węzłów” (tj. ironii i antropologii) z jednej strony oraz na przykładzie jej znaczących, arcydzielnych, a niedoczytanych realizacji poetyckich - z drugiej. Jest to więc Norwid „opowiedziany” przez lekturę: uważną, głęboką i bliską, a zarazem osadzającą tekst w kontekstach [...]

Projekt czytania uważnego, głębokiego i bliskiego wydaje się tu budującą obietnicą, po tylu przecież porażkach prób syntezy „odgórnej" na obszarze badań literaturoznawczych. Pod koniec wstępu pojawiają się dwaj hermeneuci, jak można się domyślać, patroni działań Lidii Banowskiej: Paul Ricoeur - dalsza, teoretyczna jakby perspektywa, i bliższa - Ryszard Przybylski, autor prac dotyczących nie tylko romantyzmu. Właśnie on, ponieważ - jak pisze Lidia Banowska - „Przybylski jako tradycję będącą oparciem dla swojego rozumowania jawnie wskazuje antropologię chrześcijańską, traktując ją jako wyzwanie rzucone nie tylko neoformalizmowi, lecz wszelkim formom zdehumanizowanego racjonalizmu". I jeszcze jeden ważny gest metodologiczny zasługuje na odnotowanie: „Punktem wyjścia mojego myślenia [...] jest prymat dzieła nad metodą [...] to metoda podporządkowana jest dziełu, a nie odwrotnie" (s. 18). Jak wskazuje przypis, autorka wspiera się tu również poglądami Przybylskiego, który rzeczywiście odświeżył i ożywił wiele wątków literaturoznawczych, popełniał jednak nieco błędów, obciążając hermeneutykę autorytatywną dowolnością. 
Przejdźmy jednak do praktyki interpretacyjnej i wywołajmy jeszcze jedno nazwisko Hermeneuty polskiego romantyzmu, nieco - mam wrażenie - zlekceważonego przez Lidię Banowską. Hermeneuty może mniej rozpoznawalnego, ale z odpowiedzialną dyscypliną badawczą i najwyższą kompetencją historycznoliteracką wchodzącego w artystyczną komplikację dzieła - co przecież, jak zapewnia Lidia Banowska, interesuje ją przede wszystkim. Znajdujemy się na s. 157, autorka pozostając $\mathrm{w}$ okolicach połowy drugiego rozdziału (rozdz. 2, część druga: Norwid o kondycji czlowieka) wchodzi w przełom interpretacyjny wywodu regulowanego duktem pojawiających się arcydzieł- miniatur. Przywołując skrupulatnie literaturę przedmiotu do wiersza Fatum, największą wagę w sposób oczywisty przykłada do całościowych interpretacji: odleglejszej w czasie Stefana Szumana, który właśnie miniaturową arcydzielność wiersza podkreśla i - to jest ów wspomniany przeze mnie Hermeneuta - Mariana Maciejewskiego, badacza tyleż kontrowersyjnego dla środowiska literaturoznawców (ze względów ideowo-metodologicznych), co i jednego z najwybitniejszych przedstawicieli sztuki interpretacji. Interpretacja Fatum dokonana przez Stefana Szumana zdecydowanie poprzedza w czasie egzegezę Maciejewskiego. Obie wypowiedzi zdecydowanie różnią się między sobą. Szuman pisze o wierszu z pozycji estetycznej, nie interesuje go, albo brak mu narzędzi by wejść w wymiar hermeneutycznej eksploracji znaczeń tak, jak to zrobił później Maciejewski. Myślę też, że Szumanowska wizja Norwidowego wiersza ma swoją nieprzemijającą wartość, a w stopniu jeszcze większym taką rangę przypisuję interpretacji Mariana Maciejewskiego. Lidia Banowska pisze: „Oba omówienia wy dają się dziś niewystarczające, choć trudno przeszacować ich cenny wkład w rozświetlanie meandrów Norwidowskiej miniatury."(s. 160, podkreśl. B. K. Ch.)

Przyznam, że nie rozumiem tego założenia przewartościowania z kilku powodów. Najważniejszy z nich jest rezultat poznawczy egzegezy dokonanej przez Banowską i próba odniesienia fatum Norwidowego do fatum Sofoklesa. Nie widzę podstaw w wierszu do wykonania takiego ruchu interpretacyjnego. Oba utwory należą do zupełnie rozłącznej sfery mentalnej, kulturowej i dziejowej. Słowo „fatum" traktujemy i już w XIX wieku traktowano jako niekoniecznie związane ze scenerią wydarzeń w dramacie Sofoklesa.

Do Edypa fatum nie „przyszło”. On je odkrył kiedy już było, „trwało”. Nieszczęście - literalnie - spowodowała w i e d z a - „oto ten co zagadki treść przeniknął", mówi chór. Ś wi a d o m ość odsłania fatum, w i e d z a jest furtką do nieszczęścia. W wierszu Norwida ta wiedza, jakkolwiek byśmy ją rozumieli (proces, odejrzenia”), powoduje uwolnienie od fatum, pokonanie go. Sytuacja zupełnie odwrotna. I sprawa zasadnicza, ale pozostająca w związku z wcześniejszą uwagą. Nor- 
wid rzeczywiście zafascynowany był kulturą starożytnej Grecji, ale jeśli chodzi o wyobraźnię ,ontologiczną”, o rozumienie i czytanie zasady świata, był człowiekiem cywilizacji „,po Chrystusie”. Wspominany Łapiński w rozdziale „Cóż jest człowiek?" pisze, że na szczycie hierarchii wartości poety stoi rzeczywistość nadprzyrodzona ${ }^{4}$, można pójść dalej i powiedzieć, że fakt Wcielenia jest zwieńczeniem i ostateczną „wytyczną" myśli poety. Sytuacje Sofoklesa i Norwida należą do zupełnie innych światów, można je porównywać, ale spodziewając się jakich rezultatów? Porównywać można rzeczywistości, które posiadają jakieś znaczące wspólne pole. Nie da się chyba przypisać tak świadomemu biblijnie i teologicznie pisarzowi jak Norwid pozostawania w kręgu rozumienia egzystencji na obszarze świadomości antycznej Grecji. Bez względu na ogromny kulturowy szacunek, jaki poeta miał dla tej kultury. Zresztą sama autorka rozprawy pisze:

Wydaje się, że nadając XXX lirykowi Vade-mecum tytuł Fatum Norwid wraz z pojęciem Przeznaczenia wywoływał postać starożytnego bohatera [...]. J e s t to obe c n ość hipote t y c z n a, to znaczy niepotwierdzona w tekście bezpośrednim odniesieniem, a jedynie b u d o wana pośrednio - przezprzywoływany tytułem kontekst tradyc j i antycznej i ewokowany przez nią obraz świata." (s. 166/167)

I przekonuje dalej:

Za uwzględnieniem Przeznaczenia wraz z główną postacią symbolizującą podleganie jego nieuchronności przemawia jednak także wspomniana wcześniej paralela z wierszem Sfinks, w centrum którego znajduje się Edyp. (s. 167).

Na hipotezie, dla której powód daje niemal wyłącznie formuła tytułowa (a wystarczy zajrzeć do słowników polszczyzny XVIII i XIX w., żeby zorientować się, że słowo „fatum” funkcjonowało w polszczyźnie bez „ciężkich” konotacji kulturowych) nie da się zbudować proponowanej przez Autorkę ważnej sugestii interpretacyjnej. Nie da się również imputować Norwidowi takiego rozumienia Przeznaczenia, jak chciałaby to zrobić Lidia Banowska. Sfinks również nie przywołuje Edypa, jest obrazową strukturą, figurą sfunkcjonalizowaną, przez którą wypowiada się jednoznacznie najdonioślejszą prawdą o człowieku naszej ery. $\mathrm{Na}$ s. 173/ 174 pojawiają się interesujące cząstkowe rozpoznania, ale końcówka podrozdziału (s. 174) zdaje się znów narzucać ryzykowne sądy.

I teraz można by postawić pytanie o logikę i uzasadnienie kontekstów interpretacyjnych wybieranych przez Lidię Banowską, wracając do Fatum Maciejewskiego.Ten uczony nie sięga do takich (kontekstów), które musimy szczególnie

\footnotetext{
${ }^{4}$ Z. Łapiński, Norwid, s. 55.
} 
uzasadniać, czerpie z głęboko eksplorowanej świadomości egzystencji i postawy chrześcijańskiej Norwida, mówiącego w jednym z listów do przyjaciela, że „[...] proboszcz Twej parafii więcej od Sokratesa wie o rzeczach nieśmiertelności[...]" (do Mieczysława Pawlikowskiego, Paryż 12 marca 1859). I w swoim niezwykle p r e c y z y j n y m wywodzie aktualizuje badacz lubelski podmiotowe źródło wierszowych rozwiązań. Jest to najpewniej trudna do przekroczenia praca (Maciejewskiego) interpretacyjna, którą można dopełniać, kontynuować, co autorka czyni w dalszych fragmentach.

Nie do przyjęcia jest jednak zamknięcie komentarza do Fatum, w którym określa się ostatnią frazę wiersza jako ironiczną. Żadną miarą nie można tam dostrzec ironii, nie rozumiem ostatnich zdań podrozdziału ze s. 202.

Czytając pozostałe dwie interpretacje, w których Lidia Banowska starannie rozbudowuje w większości uzasadnione konteksty, miewa się wrażenie, że jednak kształt wiersza - nieco wbrew deklaracjom ze wstępu - przez te konteksty bywa dystansowany. Spisuję to jednak na karb w n i k li w oś c i te mat y c zn e j Lidii Banowskiej, która chciałaby odświeżyć znaczenia „zużytego” nieco języka norwidologii.

Pewien niedosyt związany z wymiarem interpretacyjnym tej książki wymagałby podjęcia problematyki wierszy od podstaw, w recenzji raczej nie ma na to miejsca, zaznaczę zatem, już bez uporządkowania dyktowanego układem rozprawy, wybrane kwestie. Pisze autorka na s. 138 o wierszu Do Zeszłej:

W wierszu tym mówi się o Chrystusie jako Osobie właśnie:

[...] wzlećmy już dalej!...

Tam gdzie jest $\mathrm{N}$ i k t $\mathrm{i}$ jest $\mathrm{O}$ s o b ą [...]

Rozpoznanie to, rażąco chybione (zob. np. interpretację Stefana Sawickiego), rozpoczyna wątek (strona kolejna) niedający się zaakceptować. „N i k t i O s o b a odnoszą się do Tego, Który przez Norwida nazywany często bywa Przedwiecznym (oczywiście pamiętamy o Jedności Osób Trójcy). Żaden z teologów nie ośmieliłby się obdarzyć Chrystusa słowem Nikt, podczas kiedy wierszowy paradoks jest głęboką Norwidowską intuicją nieobejmowalności Przedwiecznego właśnie - Boga Ojca. Autorka powtarza błąd na s. 259 i znów buduje na nim określony wywód. Prace norwidologiczne zgromadzone zostały w książce starannie i obficie, czytelnik natomiast miewa wrażenie, że wykorzystanie literatury przedmiotu jest trochę niezintegrowane, niewspółmierne do wagi wcześniejszych ustaleń - z tradycji literaturoznawczej (brak rzeczywistego przemyślenia i łącznej - s p a j a j ą c e j - kontynuacji refleksji poprzedników). 
Wątek personalistyczny (wyjście w stronę XX wieku) bardzo ważny, o tym sporo również pisano (nadmieniano), tutaj można było spodziewać się mocniejszej ekspozycji Norwida jako determinanty myśli Karola Wojtyły/ Jana Pawła II. Nie jestem przekonana natomiast, że zwłaszcza Maritain tak bardzo do Norwida ,przylega”; w większym stopniu być może Mounier, ale to również kwestia otwarta. Rozumi e m jednak, ż e chodziło o zarysowa nie kręgów możliwy ch powinowactw, dyktowanych przez przyjętą przez autorkę postawę wobec dziewiętnastowiecznego poety.

*

Jak powiedziałam wcześniej, myślenie autorki o Norwidowskim problemie „Bytu” i 'światło-cienia”, zbudowane zostało ostatecznie na kilku wierszach poety, niezwykle (kilku najbardziej?) nośnych z lirycznej twórczości poety. Wierszach, które przyciągają i zyskały opisanie przez najwybitniejszych znawców Norwida. Można by powiedzieć przewrotnie, że fascynacja Lidii Banowskiej tymi wierszami stała się pretekstem do jej wyborów, była głównym powodem, by o tych lirykach pisać. Oczywiście jest to moje świadome przerysowanie, by na marginesie spraw i rzeczy, które w rozprawie zaistniały (czasami bardzo namiastkowo) podjąć problem ważny dla badań nad Norwidem. Od tego momentu interesuje mnie perspektywa szersza, właściwa raczej badaniom nad poetą, aniżeli książce, od której wyszłam.

W refleksji nad jego dziełem dominuje raczej podejście tematyczne, zatem i wiersz staje się miejscem dobywania myśli, jakby nadzwyczaj ważny u Norwida (we wszystkich jego utworach) porządek dyskursywnyprzemieścił się również na myślenie o liryce, która powstaje wodmiennym porządku twórczym, różniącym się od pozostałych rodzajów i gatunków. Praca nad poezją w obecnej norwidologii wspiera idee, myśli, teorie etc. albo - czytana samoistnie - prowadzi zdecydowanie w tym kierunku. Oczywiście, nie dziwi taka postawa np. u filozofa (vide; Fortepian Szopena zinterpretowany przez Władysława Stróżewskiego), ale niepokoi w wielu innych wypadkach. Nie chcę powiedzieć, że idee są nieważne, ale że są uwikłane tak głęboko i w sposób nieoczywisty w strukturę wiersza, że często dobycie ich staje się bardzo trudnym zadaniem, równie często trwa przez dziesięciolecia, w ustawicznych powrotach do tego samego utworu. Im wiersz mniejszy, tym ta trudność bywa bardziej złożona. To jest osobna rzeczywistość badań nad poezją; z tej prawidłowości nie zawsze chyba chcemy zdać sobie sprawę. Osobna i najtrudniejsza.

Podstawowym, pierwszym zadaniem interpretatora jest ro z w i ą z a n i e p r oble m u e s te ty c zn e go wi ers za, tzn. przeczytanie go jako dzieła sztuki, integralnie, czynności w rodzaju liczenia rzeczowników etc. niewiele tu 
pomogą, odwrotnie, zdezintegrują utwór. Takie działania mogą pojawić się później, jeśli okaże się, że „liczba rzeczowników” istotnie współtworzy to, co nazwałam problemem estetycznym utworu, pełni określone funkcje. Bo problem estetyczny przekracza wymiar językowy, chociaż z niego wyrasta. Jest obecny na trudnym do skonkretyzowania przecięciu struktury liryku i jego „komunikatu”, przesłania, obejmuje całość, integralność utworu, by na tym wszystkim się ukonstytuować. Na obszarze interpretacji liryki panuje absolutna ścisłość, nieprzypadkowość, niedowolność. Rzecz znana jest oczywiście niektórym, ale na zasadzie bardziej może apriorycznej. I trochę żal znakomitej liryki Norwida, by zamieniać ją w dziedzinę wyłącznie myśli, nawet bardzo doniosłej. Myśl i idea w liryce wybrzmiewa nieporównywalnie mocniej, a to co w niej nie jest dyskursem, domaga się szczególnego, wypracowanego uczciwie uwzględnienia. Bo przecież jeśli ta idea pojawi się w trakcie rzeczywistego, estetycznego „rozwiązywania” wiersza, jej większą niż w porządku dyskursywnym „siłę rażenia” zrozumiemy dopiero skupiając się na tym, co w poezji przekracza samą myśl, a jednocześnie jest jedyne w konkretnym wierszu. Taki sposób postępowania z liryką wymaga czasu, co przekłada się na możliwość/niemożliwość zaistnienia obszernych tomów, często krystalizuje się przez pokolenia. Sprawa kontekstów wykorzystywanych do interpretacji też jest złożona i również domaga się precyzji. Kontekst (filozoficzny, kulturowy, kontekst innych sztuk..) powinien dyktować sam wiersz; i chyba w większym stopniu, niż np. realia epoki, realia biografii...To są kwestie szczegółowe do rozwiązania (funkcjonalnego) w odniesieniu do konkretnych przypadków. Doświadczenie interpretacyjne uczy rozróżniać te sytuacje. Dokonane opisy wierszy Norwida wychodzą z rozmaitych przesłanek różnych metod, potrzeb, osobowości naukowych, etc. dlatego też znajomość i lektura prac istniejących nie powinna być „linearna”, ta znów może interpretatora wodzić na manowce. W ogóle sztuka interpretacji, a może szczególnie wierszy Norwida jest być może najtrudniejszą z czynności norwidologa (poezjoznawcy), wymaga oprócz naturalnych predyspozycji (słuch literacki), łączenia umiejętności edytorskich (jeśli nie dysponujemy przepracowaną podstawą do działań interpretacyjnych), świadomości teoretycznej, historyczo-biograficznej i jeszcze innych; być może największej i dojrzałej samodzielności naukowej. Decyzje twórcze autora spełnionego artystycznie wiersza nie są przypadkowe, odciskają ślad w głębokiej strukturze wiersza i nie ma właściwie możliwości, by wiersz naprawdę zrozumieć bez wysiłku rekonstrukcji tych „śladów”. „Pionowy” wymiar norwidologii wydaje się trochę zaniedbany. Zwracam na niego uwagę, nie próbując w żaden sposób umniejszyć wagi badań nad językiem poety, kontekstami etc., chodzi raczej o „symetryczny”, „proporcjonalny” rozwój całej norwidologii. 
Książka Lidii Banowska skupia w jakiś sposób, pośrednio, wszystkie poruszone kwestie, nie wprost również stawia pytania o naturę osobności i odrębności badawczej poetyckiego dorobku Norwida, dlatego dobrze, że zaistniała.

\title{
„PIONOWY” WYMIAR NORWIDOLOGII
}

\author{
Streszczenie
}

W szkicu podjęty zostaje problem ironii Norwida, powiązanej z jego antropologią. Kwestia ta pojawia się w ramach dyskusji z książką Lidii Banowskiej (Byt i światłocień. O antropologii poetyckiej Norwida). Rozważania prowadzą do konkluzji, że zadaniem interpretatora jest rozwiązanie problemu estetycznego wiersza.

Słowa kluczowe: Lidia Banowska; Norwid; liryka; wiersz; problem estetyczny.

\section{THE "VERTICAL" DIMENSION OF NORWIDOLOGY}

\section{Summary}

The sketch deals with the problem of Norwid's irony related to his anthropology. This issue appears in discussion with the book by Lidia Banowska (Byt $i$ światłocien. O antropologii poetyckiej Norwida). The consideration lead to the conclusion that solving the aesthetic problem of the poem is the interpreter's task.

Słowa kluczowe: Lidia Banowska; Norwid; poetry; poem; aesthetic problem.

BernadetTA KuCZera-Chachulska - profesor nauk humanistycznych, pracuje w IBL PAN. Autorka trzech książek o Norwidzie, a także innych z zakresu literatury romantyzmu, XX wieku i estetyki literackiej. Do 2020 r. pracowała w UKSW, gdzie kierowała Katedrą Badań nad Romantyzmem i Twórczością Cypriana Norwida (rozwinęła w niej badania nad twórczością Norwida). Utworzyła tam również Zakład Aksjologii i Estetyki Literackiej, czasopismo literaturoznawcze „Colloquia Litteraria”, a także serię „Problemy romantyzmu”, w której ukazało się 14 tomów, w tym kilka poświęconych w całości Norwidowi. Przez trzy lata do 2019 r. sprawowała funkcję dyrektora Instytutu Filologii Polskiej WNH. 